\title{
The Challenge of Managing Insurgency in Nigeria (2009-2015)
}

\author{
Akume, Albert. T \\ Department of Public Administration, CASSS, Kaduna Polytechnic, Kaduna State-Nigeria \\ yimaalbert@yahoo.com \\ Godswill, James Ph.D
}

Department of Sociology, Kaduna State University, Kaduna State-Nigeria

\section{Doi:10.5901/mjss.2016.v7n1s1p145}

\section{Abstract}

The effort by the government to eradicate insurgency has been slow and costly in terms of public funds spent, lives and properties lost. This has made the citizenry to question the efficacy of the methodology adopted by the government to wipe out the menace. It is against this backdrop that this paper uses the documentary research method to examine the reason why the government is unable to contain the threat of insurgency in Nigeria. In the review, it was discovered that government's agencies' opportunistic behavior accounts for the poor performance of the government to wipe outinsurgency in Nigeria. To effectively manage the situation this paper recommends that the government should mitigate the corruptionentrenched in her security agencies, enhance the capabilities of her security agencies by providing them appropriate working tools, engender participatory governance, stimulate inclusive economic development that will reduce poverty.

Keywords: Agents,Boko-Haram, Connectedness, Corruptionand Security Vote

\section{Introduction}

Insurgency and its associated insecurity trouble is a global problem that has continued to challenge state authority today.Some countries have been able,independently;to effectively quell such uprising others are still grappling with the problem of how best to handle it. The inability of most countries to handle the situation effectively hasin part exacerbated social disorder in those countries.Conflictis the outcome of perceived irreconcilable opposing interest, concerns, needs and positions between individuals, groups, organization/institutions and societies that have interacted whether in ad-hoc or permanent relations.It is aggravated by the desire of one group to attain its selfish interest (Nnamdi 2005 cited in Akume 2011:4) over those of the other groups.Conflictas anevident character of social interactionscould be functional or dysfunctional. It is functional whenthe different parties to the dispute openly and sincerely engage in resolving it.It ishowever, dysfunctional if the process of resolving the rowhas an overtly coercive or contentious character (Gurr cited in Danjos 2012).

Factors that accountsfor conflicts in societyaccording to Amusan and Jegede (2012:78-80) are poverty, migration, resources, and domination. Theelements that fuel such disagreement are inequalities, exclusion and bad governance; these are prevalent in most developing societies and Nigeria is not an exception. The poor management of these elements is often the remote cause of conflict. Although, Nigeria is crises prone, the post-2009 Boko-Haram aggression represents a whole new dimension toviolent crisis Nigeria has experienced in the past. The range of narratives that have grown around the group's origins, motivations, and future plans remains a matter of debate(Shuriye and Huud 2013:107)but the reality of their destructive force was not in doubt owing to the havoc ithas unleashed onthe northeast,on the federal capital, Abuja,thepersistent violent attacks on communities, government institutions, the United Nations building, and churches (Shuriye and Huud 2013:107).

In a bid to curtail the wantondestruction of lives and properties orchestrated by the group,the government had sought to eliminate the challenge with little impact just as the activity of the group has continued unabated. The question that thispaper seeks to answer is why was the government unable to stamp-outthe Boko-Haramchallenge in Nigeria from during this period? Arising from this question the objective of this paper is to examine the main reason that have undermine the government effectively mitigating the insurgency question in Nigeria. To achieve this goal this paper adopted and utilized the qualitative and analytical research methods. These methods assisted this paper to carefully identify and examine the different but interlinking factors that combine to undermine government capacity to curb insurgency in Nigeria from 2009-2015. 


\section{The Boko-Haram: Origin, Causesand Acceptability}

There are conflicting accounts on the origin of the sect in northern Nigeria. The first account holds that the sect is a splinter group of the Maitatsinethat evolved in the 1970s. The Maitatsineleader had a strong distaste for Western influence as well as refused to accept the legitimacy of the state (Danjibo 2009:6-15).Another account tiesthe origin of the sect to a group of radical Islamist youths who worshiped at the Al-Haji MuhammaduNdimi Mosque in Maiduguri, the capital of Borno state in the 1990s (ICG2014:7). The sect was radical in its teachingand had large followership in most states in northern Nigeria. It was however,in Borno, Yobe and Bauchi states, that the group initially enjoyed significant influence and sympathy before its influence spread to some other states in northern Nigeria. The easy acceptability of the group in the North was because of its call for the Islamization of theregion, and if possible the whole of the country.Although this call remains adversative to the secular nature of the Nigeria-state, thedesire fittingly aligned with the expressed desire of some Northern Muslim elites whocherished the idea of changing the secular character of Nigeria to one governed and regulated by the purist Sharia Islamic code (Oviasogie 2013:25). To those who hold such desire, the beliefwas that establishing a governmental system that isbased on strict Islamic code will address the ills of society, including corruption and bad governance (ICG 2014:9) that is pervasive in Nigeria.Given this backdrop, the group supported opposition to the Muslim establishment and the government (Alao et al., 2012:5) that is opposed to the attainment of this goal.

The involvement of the group in Borno state politics further strengthened its popularity and acceptability. In short, it was Ali ModuSherrifwho had co-opted the group into his political machinery in order to guarantee his election victory against the PDP candidate and Mala, Kachallaof the AD in the contest for the governorshipsit of Borno state in 2003. After his electoral victory,Ali ModuSherrifappointed BajuFoi(who was the representative of the sect) as the commissioner for religious affairs as a settlement for the sect's supports that earned him election success(ICG 2014). The rosy relationship between Ali ModuSherrif and Boko-Haram was however short lived because the sect was becoming too intrusive, dictatorial and imposing on the state government. The embittered relationship led to the resignation of BajuFoi as commissioner for religious affairs. The decision by BajuFo wasquickly and gladly accepted by governor, Ali ModuSherrif.

In Maiduguri, the sour relationship between the group and the government was no less eventful. The severed relation had provoked the sect's leader's antagonistic preaching of vilifying the governor of corruption and for failing to wholly implement the Sharia legal system as it ought to be. The unpleasant relationship degenerated to the point that the Borno state government instituted a legal case of treason against the group in an Abuja high court. The bitter relationship between the group and the government occasioned the group to seek support from other groups which she generously got in cash and kind. To garner local support, Mohammed Yusuf, the late leader of the Boko-Haram used the funds to establish a cooperative society that catered for the needs of her member as well as to assist them set-up self-sustaining businesses. This act by Mohammed Yusuf further stimulated the sect's acceptability among northern Muslims most especially in the northeast.

Aside from the outcome, the degeneration of relationship between the group and the state government triggered three different but significantly related events in the reconfiguration of the Boko-Haram. The first event was the mass movement of some of the group members to Yobe State, evidently to set up a separate community with the aim of returning to a life under true Islamic law, that evolves a more perfect society away from the corrupt establishment (Shuriye and Huud 2013:109) the government represented.The second event was the self-exile of Yusuf Mohammed, the original leader of the group to Saudi Arabiawhile the third event relates to the fragmentation of the group into cells with different leaders.Most of the new leaders of the splinter groups felt disillusioned with the peaceful and soft manner Mohammed Yusuf, was handling the soured relations. Thethird event did not only alter the non-violent character of the sect but made the control of the other split difficult. Similarly, the initial peaceful nature that caused some members of the group to relocate to Yobe also was short-lived because of the uneasy relational nature the group had with its immediate neighbours.Most often, the sect members were engaged in confrontations with their neighbouring community which resultedto police intervention. The bloody outcome the intervention provoked the sect's reprisal attack on some police formations in the state. The attackon police formations resulted in killing as well as the confiscation of police weapons in Dapachi, Babbagana, Kanama in Yobe state (ICG 2014:10) by members of the sect.

Understanding the main cause of insurgency in Nigeria'snortheast will require a brief reflection on three theoretical perspectives which are the human development theory, Islamic state theory and political feud/elite conspiracy theory (Egbeleke 2013:10-14; Anyandike 2013:14-16 and ICG 2014:1). The thesis of the human development model is that poverty is the cause of deprivation and frustration and it is linked to violent conflictand insecurity. Contrastingly, OseiBrown (2012) contends thatthe nature of violence in northern Nigeria has never been poverty induced but rather fuelled by religious differences. While these viewsare partly plausible,we cannot discard the fact that the stark poverty, 
malnutrition, environmental degradation, marginalization in the centralized federation (IDEA, 2001:263) may also in part impel some into insurgency. Despite the challenge faced by this region, religious conflict is not the main problem of the area, although a sense of alienation and deprivation persist (IDEA, 2001:263) many of its residents. While that the region is faced by serious development challenge, it is also true that the region is not the hardest hit by poverty incidence in Nigeria. This is evidenced by the fact thatthe northwest geopolitical zone has the highest average poverty rate (77.6\%); this is followed by northeast (74.5\%) and northcentral (68.1\%) (Sowumi et al., 2012:66; BBC 2012). Based on the above data, using the poverty narrativeto justify the cause of insurgency in the northeast region ofNigeria is less impressive but it cannot be ignored absolutely as a non-causative factor.

The Islamic state theory emphasizes the desire to institutionalize Islam over the Nigerian political space through the instrumentality of the jihad as the cause of the violence. Thegoal of Islamizing the north is not solely the idea of the Boko-Haram neither should it be blamed for it. For many, establishing an Islamic state in the north (ICG 2014:8) was not negotiable.Before the rise of Boko-Haram, there have been upsurge of Islamic reformist minded groups in Northern Nigeria who share broadly a common stated goal of adopting and implementing a purist vision of Islam based on the Sharia legal system. The struggle to Islamize the north using state power could be traced to 1965 and peaked in 2000 (IDEA, 2001:75) with most northern states governors adopting the Sharia legal system (IDEA, 2001:75) in 2000 in their different jurisdictions.

The third narrative is framed around the political feud/elite political theory which portrays northern elite strong desire by to wrist back political power that the region had lost to a southern minority.To this group the political power to govern is seen as a birth right which should not be given away; and if it has been lost, it shouldrepossess using whatever methodpossible. Theory also holds that the Boko-Haram is a political tool used by aggrieved northern elitesto make the country ungovernable for President Jonathan who had deprived the north of her opportunity to rule by contesting for the presidency in 2011.Their grievance is built on the argument that since the two terms of the south had been exhausted by president Obasanjo it was the turn of the north to rule even after the sudden death ofPresident Yar' Adua in 2009 ,despitethe express provision by the constitutional that the vice president is to completethat term. Failure to stop the vice president from becoming the president after the death of the president, the decision by President Jonathan to contest for a second term did not go down well with the northern hegemonic groups who saw the decision of the incumbent president to re-contest the presidential election as depriving the North of its right to rule.

This may have explained the group frustration,silence and unwillingness of northern elders to outrightly condemn in strong terms the activities of the group in the region. On the contrary, the silence in some quarters may not be unconnected with the fact that those who earlier condemned the activities of the group were silenced; such was the case of the General Shuwa. This glaring danger may have informed the decision of some of the northern elders to keep their mute to the activities of the Boko-Haram even though some of them may not be pleased with what was happening. Although, one may be tempted accede that the various theoriesare at best speculative. But, given the deepening poverty (WorldBank 2011 \&2013), the establishment of Sharia legal system in most states in northern Nigeria by the state government, coupled with the unholy political struggle among contesting groupsto wrest control over state power,one cannot but concurthat these presuppositions may in part combine to influence and fuel the Boko-Haram challenge.

Accepting or dispelling theespousesubstance and flaws in the three dominant competing narratives about the causes of the Boko-Haram crises has not take away the impact they have in shaping public thinking (Egbeleke 2013:14) about the existence of the group. From whatever perspective one sees the Boko-Haram phenomenon, it isnot unacceptable to conclude that the group is driven by Islamic ideology (Aghedo and Osumah2012:858) that is not only inspired by a real intention to institute the pure practice of Islam law (Anyandike 2013:14) and caliphate in Nigeria butalso as a political tool for undermining the efficacy of a government that is not anointed by and subject to the control of the powerful elites in the North. It should be understood that the political elites in Nigeria only play the religious card to achieve their self-centric goal,just as history has shown that religious laws have often been used by amoral charlatans for their selfish purposes (IDEA, 2001:85) to the disadvantage of the lager Nigerian population who are not within their circle irrespective of religious or ethnic background.

\section{What Went Wrong: Piecing Together the Issues}

The nature of the sect is overclouded by controversy because of the activities of other criminal groups and politicians that have covertly used the tactics of the group to inflict pains on their victim and opponents. This multi-composition has reaffirmed byAlhaji Ibrahim Gaidam, the recent pastgovernorof Yobe state who observedthat there are three types of Boko-Haram in operation in the northeast. These are:i) criminal groups' who are not connected to the real BokoHarambut who's immoral activities is easily ascribed to the group; however, upon careful investigation some of those ills 
are traceable to the handiwork of bandits operating under the mask of the sect. ii) the second group are the politicians that driven by the desire to settle scores by assassinating (Shuriye and Huud 2013:107) perceived political opponents. These nefarious acts have been easy to execute due to the nature of political engagement in Nigeria that is characterized by disrespect for due process, tension, assassination (Akuul 2011:19) and violence.iii) Last but not the least isthe real Boko-Haram. The fact that the real Boko-Haram has denied some of those shootings and bombings that fit its pattern ofattackalso evidences this truth yet it is believed in some quarters that thegroup had expanded beyond its religious composition to include not only Islamic militants, but criminal elements and disgruntled politicians as well (Alao et al., 2012:6).

A careful look at the origin of Boko-Haramshows that its initial activities were not associated with violence and destruction even though it had extremist religious character. Why did the sect resort to violence and destruction at the magnitude beingexperienced in northern Nigeria? The answer is not unconnected with the politics and repressive intervention of the Nigerian police on issues of civil engagement (Alemika 2010:6). The manner the security agencies, particularly, the Nigerian police, have extorted (Akuul 2011:19), harassed and brutalized and in some instances, involved in extra-judicial killing of innocent citizens in questionable circumstances which most often the government fails to atone for (Alemika 2000:21; NOPRIN 2007; Zumve 2012:136 and Okeshola 2013),remain an issue of concern and may not be guiltless.

A critical review of the situation show that,from 2002 to 2008, the group had conducted its activitiespeacefully even though there were concerns about the critical tone of the preaching of the leader of BHMohammed Yusuf against the government. On several occasions,the SSS had invited the leader of the group for questioning but he was released on all occasion because the SSS had no reason to detain him. between 2003 and 2004, despite the presumed peaceful façade exhibited by the group's members there are evidence of sporadic clash between the members of BH and itsneighbouring community over fishing rights to a local pound in Yobe state. Those intermittent clasheshad brought them into direct confrontation withthe police.In most of those confrontations, the groups' members were well prepared they were able to overpower the police and confiscated their weapons. The failure of the police to bring the situation under control necessitated the drafting of the military to quell the clash. The presence of the military provoked a rowin which about seventy of the group members were killed by the army (Shuriye andHuud 2013:109).

The obstinate disposition of some members of the sect to observethe law imposing the use of motorcycle helmet also caused altercation with the police during the burial of some of its members in Maiduguri.The law legalizing the use of motorcycle helmet came into effect on January 1st, 2008 but by January,2009 when the police clashed with some of the sect's members over the non-use of the helmet,compliance with that law all over Nigeria was almost non-existent. The only groups that complied with that law were the army and airforce personnel.Even the men and officers of the Nigerian police that were to enforce the law did not respect it. As such, forcing the members of the sect to adhere to that law when even most of the men and officers the Nigerian police did not respect it was a clear evidence of intimidation.Despite this sheer act of police intimidation, it was least expected that the members of the sect will take the law into their hands to attack police formationsin some part of Maiduguri the Borno state capital with devastating effects.

As usual, the military weresent in to curb the mayhem unleashed by the sect. The adamantand continued reprisal attacks on police formations by the sect members clearly showed that the group was heading for an all out conflict with the state.The inability of the sect members to exercise self-restrain and caution in dealing with the police subsequently resulted in the police killing of Yusuf (Shuriye and Huud 2013:109), the leader of the Boko-Haram sect, Baju, Foi and Baba Fuggu. Furthermore, the police went ahead to arrest many of its members, assembled them somewhere in the northern part of Nigeria, shot and killed them one by one. Sadly, the government did nothing to condemn or ensure that those responsible for the extra-judicial killings were punished (Alao et al., 2012:6). This situation in 2009 and other politically related issues were the high watermark thatfurther souredthe once assumed cordial relationship between the Boko-Haram and the Borno State government, and later the Nigerian state.

In all this, it is evident that politics played a role in the crisis (ICG 2014:16). Obviously, the recruitment of some of the sect members by some politicians to help them win to election after which they were dumped by those who used them did not help matters. The obvious truth is that there is a strong affiliation of the sect members to some politicians.In short, the sect members were very instrumentalin guaranteeing election victory desperate politicians at all cost by recruiting the members of the sect to rig and intimidate opponents during the 2011 elections in their favour but dumped them after winning the election. The failure of those politicians to compensate the sect members did not go down well with the those sect members; the consequence was thatthe aggrieved members of the sect in seeking revenge, decided to use the guns and bombs procured by the politicians to intimidate opponents to fight the government (Alao et al., 2012:5). The altered peaceful disposition of the sect which triggered them to turn to violencewith attacks on soft targets such as places of worship, markets and motor-parks, evidenced the fact that politicians hadcreated a monster for whichthey have 
lost control of (ICG 2014).

\section{Discussion}

There are other factors that have combined to undermine the government ability to eradicate insurgency but prominent among those factors is corruption. Corruption is not a strange phenomenon in Nigeria, and in the fight against insurgency its manifestation has been expressed throughmalfeasance, misfeasance and nonfeasance.

Malfeasance is more than stealing it is the performance by public officials of deeds that they are forbidden to perform by constitutional or statutory law or by commonly accepted moral standard... misfeasance is the improper performance of lawful duties, it involves administrative activity that is within the lawful mission of an agency but violate constitutional standard or public interest. Nonfeasance is the failure of public official to perform required duties (Grover, 2008:168 - 9).

It is an activity that public officials engage in freely. To begin with, evidence shows that since the insurgency started, the Nigerian defence budget to combat insurgency had increased from 100 billion naira (\$625 million) in 2010 to 927 billion naira (\$6billion) in 2011 and 1trillion (\$6.25billion) naira in 2012, 2013 and 2014 (ICG 2014:30). According to the Leadership Newspaper 10 $10^{\text {th }}$ March, 2014 the federal government over a period of four years, has spent about N3.38 trillion to combat insurgency alone (Emeand Anyandike 2013:13\&24-25). A thorough investigation about how those monies were spent reveals that a large sums of those monies budgeted by the government for combating insurgency were misappropriated by top government, military and other security agencies' officials in collaboration with politicians and contractors supplying military hardware.

Military hardware contract has been a good arena for corruption, though often ignored;this is facilitated through the "offset" principle operated in defence procurement that is built into contractual conditionalities. Defense offset dictates that the purchasing government of the importing country obliges the supplying company of the exporting country to reinvest some proportion of the contract in the importing country. Since defence contracts involve great expenditure the offset arrangement is similarly large in value thus it is highly susceptible to corruption. Worse still, in many countries, there is almost no due diligence on potential improper check on beneficiaries from the offsets, no monitoring of performance on offset contracts, no audits of what was delivered compared to the pledges, and no publication of offset results, benefits or performance at all, which makes offsets an ideal arena for corruption. There are three main categories of corruption risk associated with offsets which are:i) Improperly influencing the need for a particular defence acquisition, ii)Influencing the competitive decision for the main contract in non-transparent ways and iii) it allows favours to be repaid to corrupt government officials via the offset contracts (T I, 2010, see also Gupta, et. al. (2000:1-31). The unholy manner the federal government had smuggled monies to South Africa in the name of acquiring military hardware to combat insurgency only explains the role corruption by public officials (agents) have played in undermining the effort to curtail insurgency in Nigeria.

Returning the issue of misappropriation and underpayment of foot soldiers, although the accusation has been refuted by top military and other security agencies officials, but the event that provoked some ground troop to fire at their GOC, (the commandant of $7^{\text {th }}$ Division in Borno state) who was immediately replaced (Blanchard 2014:9-10) and the near mutiny (Daily Sun, Monday $1^{\text {st }}$ September, 2014) situation by soldiers due to poor welfare in Adamawa state, support this fact. This has proven that that security agents' opportunistic behaviour is one of the reasons for the government's inability to eliminate insurgency in Nigeria. aside from the above, other factors that have undermined government capacity to curb and eradicate insurgency are underfunding, lack of equipment, poor intelligence, corruption complicity, interagency rivalries, and lack of effective political leadership (The Sun Newspaper, Monday, September 1 ${ }^{\text {st }}, 2014$, Vanguard, October 11 $1^{\text {th }}, 2014$, ICG 2014:32\& Blanchard 2014).

As it is at the federal agency level, so is corruption undermining the ability of the state governments in the northeast to appropriate cooperate with the federal government to aptly find solution to the problem of insurgency in those localities. Equally too, the corruption of politics in Nigeria reclines behind the government's inability to effectively battlethe Boko-Haram. Politics practiced rightly is produces good human security for the citizens, on the contrary in Nigeria, it is has been used for the wrong purpose by politicians and traditional rulers even on life threatening issue such as insurgency. Enhancing human security in a comprehensive term, which has been threatened depends on politicians and traditional leaders' greater determination and willingness to stop local support for Boko-Haram; without which the impression will persist that they are not really interested in ending the sect's (ICG 2014:36) threats. Politically, the unwillingness of most northern politicians and traditional rulers in the region to support the federal government in its war against Boko-Haram as the local civilian JTF is doing in Borno only worsen the situation.

A compelling argument for local politicians and traditional rulers support for the group is not unconnected with 
thepower shift question. To its proponent, after the death of Musa Yar' Aduait was only reasonable to allow someone from the region to continue from where the late President had stopped. But the decision of the incumbent President to retain the post was interpreted as depriving the north of its right to lead the country as so, to punish him for that, $\mathrm{BH}$ was presumably supported to blossom as a tool for making the country ungovernable for him. It was believed in the region that cooperating with the federal government to eliminate the Boko-Haram threat was assisting the president to score a huge political point that will guarantee his reelection in 2015, if he decides to. It is no wonder that the governors of Sokoto, Kano, Niger, Jigawa, Yobe and Adamawa withdrew their membership from the ruling PDP to join the opposition party. The move was not necessarily to enrich the political process, but a way of strengthening their call for power shift to the north. It is not surprising that even when the State Security Service had alerted the government of Kano state about the intended Kano bomb attacks 48 hours before it happened in 2012, nothing was done to avert it. The governors and other northern political stalwarts are not in it alone. Some northern traditional rulers are also involved in the act. Currently, a monarch is under investigation for his alleged involvement with the insurgent group. It is on record that it was latter learnt that the reason for the investigation of the monarch was connected with his alleged funding and remittances aimed at halting Ogwuche's extradition (Vanguard, 15th June, 2014) from Sudan to Nigeria. It is quite disheartening to take politics to such a detestable level. Agreed that

Politics is inextricably linked to the phenomena of conflict and cooperation. On the one hand, the existence of rival opinions, different wants, competing needs and opposing interests' guarantee disagreements about the rules under which people live. On the other hand, people recognize that, in order to influence these rules or ensure that they are upheld, they must work with others (Heywood 2007:4).

This makes politics useful, meaningful, progressive and beneficial to all. This form of conciliatory and concessionary politics is vital as it promotes close cooperation, shared values, and shared vision among stakeholders toward sustainable development (Senge 2010 cited in Sriram, et. al., 2013:131) that enhances a secured social order that is capable of defeating internal and external security threats. It also facilitates dialogue-based relationship among the various actors that will help in strengthening values like sympathy and empathy, as well as, contribute to knowledge and innovation (Zsolnai and Ims 2006 cited in Sriram, et. al., 2013:131) essential for productive governance. This form of politics is not only developmental but vital because it eliminates most of the problems of unsustainability caused by poor communication between the various interconnected and interdependent facets (Wilbanks et al., 2007 cited in Sriram et al., 2013:131) of society.

Such interconnectivity and interdependence between the various tiers of governments, political actors and the citizens, the federal, state and local governments, the government in power and the opposition, the state and the private sector, and public institutions and the citizenry foster peace. It is sad to note that in Nigeria, this vital interconnection and interdependence between the different groups especially, between the tiers of government, the different political actors and the citizenry is grossly lacking. On the contrary, these different groups have to be connected for Nigeria to be integrated and capable of focused and coordinated action against insurgency that threatens her. In this case, if there is connectedness it will not only foster cohesion and develop the means of intervention that all state actors need but are to ally withsociety as force cannot be the only means of state power and, therefore, state actors do have to make concession (Scott and Marshall 2005:633) by discarding their self interest for national goal.

The unwillingness of most northern politicians and traditional institutions in the region to support the federal government in the campaign against insurgency as the local (youths) civilian JTF are doing, may not be unconnected with the fear of alienating northern supporters (ICG 2014:33). This problem is not unconnected with the failure of the government to adequately protect her citizens. If the state had been able to protect its own in spite of the new twist to the campaign against the government by a few sectionist that the federal government is killing Muslims in the name of fighting terrorism as falsely claimed by the memo written by MurtalaNyako, the Adamawa State governor to the northern

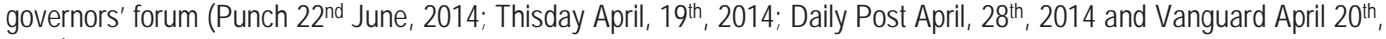
2014) the local people would still have been connected to the state.Despite the sectional division, the governors have not failed to echo loudly their call for increased security vote in their yearly budget under the pretext of containing insurgency in their various states (Premium Times 2014).

The insurgency threat has give rise to the 'security vote syndrome' in Nigeria. Security votes are funds unconstitutionally appropriated at all levels of government in Nigeria for the purpose of enhancing national security(Vanguard 2013). While there is no clear basis for allocating such huge sum as security votes, the tendency seems to be that such security votes are constantly on the increase (Obiomaka et al., 2010:26). Although:

section 14(b) of the 1999 Constitution states that the security and welfare of the people shall be the primary purpose of the government. Nowhere did the section or any other part of the statute book state that there shall be a pool of fund called security vote.... It is estimated that on the average, a Nigerian governor gets a minimum of N300 million per 
month as security vote-a sum enough to pay the minimum wage of $\mathrm{N} 18,000$ of more than 16,000 Nigerians. It is also believed that some states allegedly set about N700 million as security vote per month (Vanguard 2013).

This unwholesome practice is not limited to the states under insurgency threat. Although itspractice is much more pronounced in those states, it is a nationwide practicewhereby state governors now easily misappropriate public money under the guise of enhancing national security (Obiomaka et al., 2010:14) considering that it is not subject to accountability neither is it demanded nor given (Vanguard 2013). The likely reason that account for this is the obvious fact that the former old mode of outrightly stealing public funds has lost its charm, because such flagrant appropriation of public funds is easy to trace, retrieved and punished appropriately. To avoid such checks and possible exposure, political office holders in Nigeria have resorted to diverting public funds through the instrumentality of security votes. Despite the rise in security votes, the paradox is that over the past few years, the Boko-Haram sect appears to have increased their capability (Eme and Anyandike 2013:26).

Another challenge that undermined state capacity to eradicate insurgency is rooted on the initial tactics adopted by the government in solving the problem. In the management of conflict the government can either be proactive or reactive. In most instances, the Nigerian government has been mostly reactive to events even when it had prior information of a brewing crisis situation. It is unfortunate to note that even when she had information that the $\mathrm{BH}$ was stocking arms the government initially ignored the reports on the sects prior to 2009 (Alao et al., 2013:5). Little wonder that the escalation of insurgency attacks in early 2010 caught the government flat-footed (ICG 2014:30). The Nigerian state has over the years, proven to both critics and proponents of the state that she is a country with a very poor record of managing internal crisis. This is evident in the carefree manner it initially responded to the $\mathrm{BH}$ issue.lt was only when violent attacks by the $\mathrm{BH}$ became persistent that the government began to scramble to quell the threat using repression which include arrest, detention, proscription of the group, declaration of emergency rule in part of the north, and killing of the sect's members (Aghedo and Eke 2013:98\&Agbiboa 2013:79) as well as the enactment of anti-insurgency legislation.

Although the government has relied majorly on the use of coercive force,in recent times, she somewhat soft pedaled to the calls in some quarters to consider the option of dialogue (Kantiok, 2013), grant of amnesty, or even to compensatesome members of the group that had suffered losses due to Nigerian security agencies high-handedness.In response to this call,the government set-up a committee to dialogue with the group but sadly, nothing reasonable came out of it. Similarly, the government made efforts to address the socio-economic issue that was presumed to invigorate insurgency; that is, injustice, inequality, poverty, infrastructural decay and unemployment.It was to resolve in part these problems thatthe federal government launched the multi-billion naira Northeast Development Programmein early 2014, the question however remains whether corruption will allow this plan to succeed.

It is estimated that about $\$ 6$ billion (BusinnesDay, Thursday June $5^{\text {th }}, 2014$ ) has been spent to fight insurgency but the result is awkwardly dismal. The question then is what is the impact corruption on interagency effort to eradicate insurgency?Administratively, this can be seen in the lack of effective agency control and connectedness.Control is about influence essential for orderly moderation of the actions and behaviours of individuals or groups in the performance of their duty. It connotes discipline and the ability to abide within the boundaries set by the law. To strengthen and ensure better intra and inter organizationalcoordination and synergy in a network relationshipentails adopting appropriate control (Sriram et al., 2013:125) measures especially where information sharing (Stoll, et. al., 2012:1) and cooperation is needed to foster strong bonds of interdependence between allied organizations. Network relationship can only be strengthen by creating information ecosystem that that allows different agencies working on similar task to coordinate and share information (Stoll, et. al., 2012:1). Aside from the above, control engenders harmony and compliance to constituted authority and these are key dynamic property of connectedness (Sriram, et. al., 2013:133)which promote sustainable (Sriram et al., 2013:124) action and success.

Connectedness refers to the internal relationships of actors and components dependencies between stakeholders, units within and outside the organization, local networks of trust, formal and informal associations, social networks, knowledge spillovers, patterns of mobility within and from outside the network (Sriram et al., 2013:124).

Its absence in interagency or allied agencies has consequences for low motivation, distrust, poor communication, institutional flaws (ICG 2014:33) conflicting personal or group interest that in the end hampers the achievement desired of goals. Opportunistic behaviour that arise from as a result of its absence is better captured by the agency theory. The theory sees the relationship between the principal and the agent as contractual one which involves delegation of some decision making authority to the agent (Luhman and Cunliffe, 2012:1 and Law 2006:21) by the principal. The relationship between the state and the agent is one of the oldest and commonest codified modes of social interactions (Ross, 1973:12).Interior to the theory is the problem of opportunistic behaviours by the agent which raises the concerns of drawing up a contract that permits the agent's performance to be measured and incentivized so that the agent actwith the interest of the principal in mind (Luhman and Cunliffe, 2012:1). 
This concern is heightened because of the problem of information asymmetry ad hidden agenda on the part of the agent which is hard to decipher by the principal in the process of decision making under certainty. Ironically, this condition has consequence for adverse selection, moral hazards and opportunism by the agent. Opportunistic behaviours include shirking, systematic soldiering or working at less than optimal efficiency (pass, et, al., 2005:416) corrupt practices, collusion extortion, wage theft, and free riding (Mbaku, 2008). These are easily engaged in by agents given that the principalcannot effectivelymonitoror control the agent (Pass, et. al., 2005:416) because they are far remote from each other. More so, because interest differ (Oxford, 2003:439), the agent has hidden agenda (Pass, et, al., 2005:416), these difference permits the agent to act in ways that do not always maximize the welfare of the principal (Law, 2006:21)an is responsible for increasing agency cost (Varese, 2003:439). Resolving this problem calls for proper motivationwhich on the long-run resolves the problem of opportunistic behaviours, reduces agency cost and it guarantees the realization of pareto efficiency (Ross, 1973:139) of interest where both parties to the contract are winners. Failure to ensure this balance permits corruption to thrive in the execution of public function which in turn weakens connectedness.

The frailinteragency connectedness has continued to affect the focus of the various security agencies (Blanchard 2014:9)as reflectedin-fighting between top military officers, collusion and sabotage with the Boko-Haram(Daily Sun, September 1't, 2014:5; Vanguard, October 11, 2014) by some officer who inform thesect about military intended operational plans against Boko-Haram cells,and diversion of funds meant for the successful execution of the antiinsurgency campaignto personal use by top military officers.Others are thenon-remittance of monies due to the footsoldiers, or in some cases, the underpayment (of N1000 instead of N1500 daily allowance) of troops on the ground (Daily Sun Newspaper, $11^{\text {th }}$ June, 2014), inadequate and the use of obsolete equipment by the military compared to those used by Boko-Haram,selling of military hard wares to Boko-Haram. All these are evidence of opportunistic and corrupt behaviours.

The government (executive and legislature) in striving to maintain social order which has been disrupted by insurgent activitiesis required to appropriately allocatefunds that will aid her institutions to rightly confront such disruptive forces. It does not make any sense if budgetary allocation is made and such funds do not get to where they are needed andused for the purpose budgeted for. While monies had been, the corresponding poaching on those funds allocated for combating insurgency did not help the cause of exterminate insurgency. It is equally sad to note that fundsreleased to acquire equipment and for maintaining personnel welfare are systematically been skimmed off at the top (Blanchard 2014:9). This contravenes the functionalist requirement of the state to curbinsecurity and protect the people. To appropriately uphold order and deliver social stability,funding must align with, and strengthen organizational(Heywood 2006:86) capacity of those state agencies to perform their responsibility rightlyln essence, the state must not only provide,protect and ensure that such funds are judiciously used,but must enforce its accountabilityso as facilitate connectedness within and among the agencies involved in restoring social order.

Real connectedness induces the concord of interest and functionality. It also demands that funding should align with assigned responsibility, ensuringits proper use and accountability;this is necessary, and in part, forms the basic dimension of an agency relationship (Law 2006:6). This is indispensableconsidering that different actors are involved and that they have different intereststhat are likely to be expressed in conflicting preferences (Scott and Marshall 2005:632), if it is not properly controlled it is detrimentalto the attainment of the goal being pursued. The failure to build-on and entrench the ideals of connectedness has allowed these differences to deepened as each agency wants to illegally have a share of the funds appropriated for curbing insurgency;despite the consequence that such opportunistic behaviours may have on the society. This is the main problem that has undermined Nigeria's capacity to effectivelystamp out insurgency thereby necessitating the government to seekfor external assistance. It is disheartening to note that since 2009 to date the federal budgeted allocation for combating insurgency has been on the increase yet, the successes recorded is low compared to the about $\$ 6$ billion of public funds spent for the purpose in just four years with an unimpressive outcome to show for it.

\section{Conclusion}

It is quite obvious that failure to contain corruption makes it difficult to maintain social order even in the face of the use of repressive force. Despite government's repressive response to the Boko-Haram question the government nonetheless scrabbled together and launched a multi-billion naira northeast development plan aimed at improving infrastructure, boosting the economy, creating jobs, and eradicatingpoverty in the region. Whether this plan will be followed through remain a mystery for now. Although this initiative is to help resolve some of the reasonsattributed to be the cause of insurgency in the northeast, government has however failed to combat corruption which is the root cause of poverty, inequality and deprivation for most Nigerians. The inability to contain corruption has permitted it to resurface in the opportunistic behaviour by the agent and is the cause of institutional inefficiency that has underminedthe state's capacity 
to perform her responsibilities protecting the people effectively. It is therefore recommended that,to curb insurgency, drastic political effort must be made by the government to address institutional corruption (Manni 2012:50) and improve the economy which is vital for sustainandenhanced human security.

\section{References}

Agbiboa, D. E (2013) No Retreat No Surrender: Understanding the Religious Terrorism of Boko-Haram in Nigeria. In: African Study Monographs, Vol. 34, No. 2. Pp. 65-84.

Aghedo, I and Eke, S. J (2013) From Alms to Arms: The Almajiri Phenomenon and Internal Security in Northern Nigeria. In: Korean Journal of Policy Studies, Vol. 28, No. 3. Pp. 97-123.

Alao,D. O., Atere, C. O and Alao, O (2012) Boko-Haram Insurgence in Nigeria: The Challenges and Lessons. In Singaporean Journal of Business and Management Studies. Vol. 1, No. 4. Pp. 1-15.

Alemika, E. E. O and Chukwuma, I. C (2000) Police-Community Violence in Nigeria. Abuja: The Center for Law Enforcement Education and National Human Rights Commission.

AbuAlemika, E. E.O (2010) History, Context and Crises of Police in Nigeria. Being Presentation at the Biennial Retreat of the Police Service Commission on the Theme, Repositioning the Nigerian Police to Meet the Challenges of the Policing a Democratic Society in the Twenty-First Century and Beyond Held at the Le Meridian Hotel, Uyo, Akwa-lbom, November 1-4, 2010.

Akume, A. T., Solomon, M and Bello, M. F (2011) Conflict and the Challenge to Effective Conflict Management in Kaduna State. In: Lapai Sociological Review. Vol. 3, No. 2. Pp.1-18.

Aghedo, I and Osumah, O (2012) The Boko-Haram Uprising: How Should Nigeria Respond? In: Third World Quarterly. Vol. 33, No. 5. Pp. 853-869.

Amusan, L and Jegede, D (2012) Human Insecurity and Monetary Integration of ECOWAS: Negotiating the ECO. In: University of Calabar Multi-Disciplinary Journal of Research and Development Perspectives. Vol. 1, No. 1 June. Pp. 70-84.

Anyandike, N. O (2012) Boko-Haram and National Security Challenges in Nigeria; Causes and Solution. In: Journal of Economics and Sustainable Development. Vol. 4, No. 5. Pp. 12-23.

BBC (2012) Nigerians Living in Poverty Rise to Nearly 61\%. Retrieved from www.bbc.com/news /world-africa-17015873

Blanchard, L. P (2014) Nigeria's Boko Haram: Frequently Asked Questions. Being a CRC Report Congressional Research Service. Washington, DC

Donaldson, L (1990) A Rational Theory Organizational Economics: A Reply to Barney. In: Academy of Management Review. Vol. 15. Pp. 394-401.

Danibo, N. D (2009) Islamic Fundamentalism and Sectarian Violence: The Maitatsine and Boko-Haram Crises in Northern Nigeria. Being a Report Prepared for the Institute of African Studies, University of Ibadan, Nigeria.

Danjos, D. D (2012) Causes and Effects of Conflict on Nigeria's Development. In: University of Calabar Multi-Disciplinary Journal of Research and Development Perspectives. Vol. 1, No. 1 June. Pp. 85-93.

Donaldson, L and Davis, H. J (1991) Stewardship Theory or Agency Theory: Governance and Shareholders Returns. In: Australian Journal of Management. Vol. 16, No. 1. Pp. 49-65

Egbeleke, A (2013) Rethinking Boko-Haram: Contending Perspectives Among Nigerians in Diaspora and Youths. Being A Project Submitted to the International Institute of Social Studies for the Award of Masters of Arts in Development Studies. The Hague, Netherland.

Eisenhardt, K. M (1989) Agency Theory: An Assessment and Review. In: Academy of Management Review. Vol. 14. Pp. 57-74.

Eme, O. I and Anyandike, N (2013) Security Challenges and Security Votes in Nigeria, 2008-2013. In: Kuwait Chapter of Arabian Journal of Business and Management Review, Vol. 2 No. 8. Pp. 10-35.

Gupta, S, Luiz, D-M and Sharan, R. (2000) "Corruption and Military Spending". Being an I.M.F Working Paper, No. WP/00/23.

International Crisis Group (ICG) (2014) Curbing Violence in Nigeria II: The Boko-Haram Insurgency, Africa Report No 216, 3rd April, 2014. Brussel: Belgium.

Kivisto, J (2007) Agency Theory as a Framework for the Government-University Relationship. Being an Academic Dissertation Presented to the Faculty of Economics and Administration, University of Tampere, Finland.

Kantiok, J. B (2012) Boko-Haram, the Government and Peace Negotiation. Being A Paper Delivered At A Conference Organized by the Centre for Democracy and Development. Retrieved from www.cddwestafrica.org/inde.php/en/photo-album/24-insecurity-in-thenorth-east/detail/145-james

Knott, J. H. and Hammond, T. H. (2007) Formal Theory and Public Administration. In: Guy, B. P. and Jon (ed) Handbook of Public Administration. London: Sage Publications. Pp. 99-110.

Law, J (2006) Agency- Relations. In: Law, J (ed) Oxford Dictionary of Business and Management (4thed). New York: Oxford University Press.

Manni, N (2012) Boko-Haram: A Threat to African and Global Security. In: Global Security Studies, Vol. 3, Issue 4. Pp. 44-54.

Mbaku, J.M. (2008) Corruption in Developed and Developing Countries - Public Choice Theory and Corruption Control. "http://science.jrank.org/pages/8848.

Obiomaka, E., Nwakoby, I., Onwumere, J and Uche, C (2010) Legitimizing Corruption in Government: Security Votes in Nigeria. Being an ASC Working Paper 91/2010 of the African Studies Center. Leiden: The Netherland.

Odi, N (2014) Impact of Corruption on Economic Development in Nigeria. In: Mediterranean Journal of Social Sciences, Vol. 5, No. 6, 
April. Pp. 41-46.

Okeshola, F. B (2013) Human Right Abuse by Nigerian Police in Four Selected States and the Federal Capital Territory, Abuja. In: British Journal of Art and Social Sciences. Vol. 13, No. II. PP. 242-250.

Osie-Brown, A (2012) Sanusi, Boko-Haram andNorthern Nigeria's Poverty. Insight Monday 20th, 2012 Retrieved from www.osei-browninsight.blogspot.com/.../sanusi-boko-haram-and -northern-nig...

Oviasogie, F. O (2013) State Failure, Terrorism and Global Security: An Appraisal of the Boko-Haram Insurgency in Northern Nigeria. In: Journal of Sustainable Society. Vol. 2, No. 1. Pp. 20-30.

Pass, C., Lowes, B and Davies, L (2005) Collins Dictionary of Economics (4thed). Glasgow: HarperCollins Publishers.

Premium Time, (2014) 36 Governors Seek Increased Security Votes, State Police, To Combat Boko-Haram. Retrieved from www.premiumtimesng.com

Ross, S. A (1973) The Economic Theory of Agency: The Principal's Problem. American Economic Association. Vol. 63, No. 2. Pp. 134139.

Sapru, R. K. (2008) Administrative Theory and Management Thought. New Delhi: Prentice Hall of India Private Limited

Scott, J and Marshall, G (2005) Oxford Dictionary of Sociology (3rded). New York: Oxford University Press.

Sriram, K., Ganesh, L. S and Madhumathi, R (2013) Principle of Sustainable Development of Businesses on the Adaptive Lifecycle Dimension of Interconnectedness. In: European Journal of Sustainable Development. Vol. 3, No 2, 3. Pp. 123-144.

Stoll, J., Foot, K and Edwards, W. K (2012) Between Us and Them: Building Connectedness within Civic Network. Retrieved From...

Sowumi, F. A., Akinyosofe, V. O., Okoruwa, V. O and Omonona, B. T (2012) The Landscape of Poverty in Nigeria: A Spatial Analysis Using Senatorial District-Level Data. In: American Journal of Economics. Vol. 2, No. 5. Pp. 61-74.

Svensson, J. (2005) Eight Questions about Corruption. In: Journal of Economic Perspectives-Vol. 19, No. 3.Pp. 19-42

T. I. (2010) "Defence Offsets: Addressing the Risk of Corruption and Raising Transparency". www. transparency.org.

Vanguard, (2013) Insecurity: What Has the Security Vote Secured? Retrieved from www.vanguardngr.com/2013/15/ insecurity-what-hasthe-security-vote-secured/ last accessed June $22^{\text {nd }} 2014$.

Varese, F (2003) Principal-Agency Problem. In: McLean, I and McMillan, A (eds) Oxford Dictionary of Politics (2nded). New York: Oxford University Press.

Vishnoo, B. and Vidya B. (2009) Public Administration. New Delhi: Chand and Company Ltd.

World Bank (2013) poverty has increased considerably in Nigeria in Nigeria politics online. Retrieved from nigeriapoliticsonline.com/ poverty-has-increased-considerably-in-nigeria

World Bank (2011) Nigeria: Poverty in the Mist of Plenty. Retrieved from http://go.worldbank.org/J55W816ZV0

Zumve, S. I (2012) Community Policing in Contemporary Nigeria: A Synthesis of Model. In: Journal of Educational and Social Research. Vol. 2, No. 9. Pp. 132-139. 